\title{
Impact of Zonation Policy in Receiving New Students
}

\author{
Muzakki $^{1 *}$, Huldiya Syamsiyar ${ }^{1}$, H.Zulkarnain $\operatorname{Hadi}^{1}$
}

\author{
${ }^{1}$ Department of English Language Education, Hamzanwadi University \\ Jalan TGLH. Muhammad Zainuddin Abdul Majid no 132, Pancor, Selong, Lombok Timur, Indonesia \\ *Corresponding author. Email: zakimuzak108@gmail.com
}

\begin{abstract}
A zone is an area or area that has specific environmental functions and characteristics. The zoning system is applied so that students can be accepted in schools close to their domicile. The zoning system will also protect people who cannot, in addition to residents who have learning achievement by choosing schools that favorite having trouble so many people who rebelled with government policy on zoning PPDB. This system triggers chaos in a number of areas, especially in Lombok, especially in the District of Pringgasela. There are schools that are over quota so they don't can accommodate more students, even though there are still many children living around the school. There are also schools that lack students, not to mention there are poor and outstanding students who are not accommodated so researchers write titles; The Impact of Zoning Policy on New Student Admissions (PPDB) Study in SMA 1 Pringgasela East Lombok Regency in 2018/2019 Academic Year.This type of research is a qualitative research with a qualitative approach.Data collection techniques; observation, interview, documentation. Data reduction data analysis techniques, data presentation, verification. validity of data internal validity, objectivity.Based on the results of the study it can be concluded that the impact caused by the zoning policy (PPDB) namely; Provide equal distribution of education, Provide opportunities for students who have potential , Can facilitate the control of parents to students, Opportunities for students who are less capable in academic matters . Easily students come to school. Positive impact of Less Interest in Student Learning, Lack of income from operational school fees (BOS), Achievement of children becoming less (non-favorid schools).
\end{abstract}

Keywords: Impact of zoning policy, PPDB.

\section{INTRODUCTION}

A zone is an area or area that has specific environmental functions and characteristics. Zoning is the division of the city environment into zones and establish control of spatial use or impose different legal provisions Barnett, 1982 Zoning Regulations is Zoning Regulations governing the provision of zone classification, further regulation regarding land use, and procedures implementation development. There is something different from the acceptance of new students $\mathrm{n}$ public schools, namely the acceptance of new students based on the zoning system. This system causes students to study at a nearby school or in the same area as their residence based on the address on the Family Card.

This system triggered chaos in a number of areas. There are schools that are over quota so they cannot accommodate students anymore, even though there are still many children living around the school. There are also schools that lack students. Not to mention there are poor and outstanding students who are not accommodated. Smart children also cannot enter favorite schools which happen to be located far from their homes.

With the zoning system, students inevitably have to register at the nearest school, can no longer register at a school that is far away but holds a favorite status. There are no more intelligent students gathered in one school, which has been called a favorite school.

The implementation of the PPDB zoning system in the government of Ir.H Jokowi Dodo, which was led by the minister of education and culture, Muhadjir Effendy in the 2017/2018 school year. The zoning system is regulated in the Fourth Section of Permendikbud Number 17 of 2017 articles 15 and 16. It reads as follows: Article 15 which reads: (1) Schools organized by local governments must accept prospective students who are domiciled in the closest zone radius of the school ah at least $90 \%$ (ninety percent) of the total number of students received. (2) Domicile of prospective students as referred to in paragraph (1) shall be based on the address on the family card issued no later than 6 (six ) months prior to the implementation of PPDB. (3) The closest zone radius as referred to in paragraph (1) shall be 
determined by the regional government in accordance with the conditions in the area based on the amount of available capacity based on the provisions of each school's study group with the availability of school-age children in the said area. (4) (5) In a school located in a provincial/regency/city border area, the provisions of the percentage and the radius of the nearest zone as referred to in paragraph (1) can be applied through written agreement between the regional governments that border each other. (5) Schools organized by local governments can accept prospective students through: a). paths of achievement domiciled outside the radius of the closest zone of the school at most $5 \%$ (five percent) of the total number of students received; $b$ ). pathway for prospective students who live outside the closest zone of the school with special reasons include the transfer of domicile of parents / guardians of students or natural / social disasters, at most $5 \%$ (five percent) of the total number of students received. (Source: Permendikbud Number 17 Year 2017 concerning PPDB). The Ministry of Education and Culture implements a zoning system in New Student Admissions (PPDB). Director General of Primary and Secondary Education because the policy is to accommodate students unable to get a school.

This is actually an affirmation program to protect children who are unable to get school. Because the state school is funded by public taxes and it must be returned to the people. The zoning system is applied so that students can be accepted in schools close to their domicile. The zoning system will also protect the poor, besides those who have learning achievements by choosing faporite schools that experience difficulties so that many people rebel against government policies regarding zoning PPDB. This system triggers chaos in a number of areas, especially in Lombok, especially in the District of Pringgasela. There are schools that are over quota so they can not accommodate students anymore, even though there are still many children living around the school. There are also schools that lack students, not to mention poor and high achieving students who are not accommodated by the title; The Impact of Zoning Policy on New Student Admissions (PPDB) Study at Pringgasela 1 High School in East Lombok Regency in 2018/2019 Academic Year. How Does the Impact of Zoning Policy on New Student Acceptance (PPDB) Study in SMA 1 Pringgasela East Lombok Regency in 2018/2019 Academic Year?

Whereas to examine the problem of this research with Talcott Parson's Functional Structure theory Discussion of Parson's structural functionalism theory begins with four important schemes regarding functions for all action systems, the scheme is known as the AGIL scheme. Previously we must know in advance what is the function being discussed here, the function is a collection of activities aimed at meeting the needs of the system.

According to Parson, there are four important functions that are absolutely needed for all social systems, including adaptation (A), attainment of goals or goal attainment (G), integration (I), and Latency (L). the four functions must be possessed by all systems in order to survive (survival), the explanation is as follows: Adaptation : the function of the system is very important here to be able to adapt to how to cope with external situations are critical, and the system should be biased to adjust themselves to the environment also can customize the environment to kebutuhannnya. Goal Attainment; achieving goals is very important, where the system must be able to define and achieve its main objectives. Integrastion: means that a system must be able to manage and maintain the relationship between the parts that become its components, besides regulating and managing the three functions (AGL). Latency: latent means the system must be able to function as a pattern keeper , a system must maintain and improve the motivation of individual and cultural patterns.

Parson provides answers to problems that exist in structural functionalism by explaining the following assumptions; 1 . The system has an orderly property and interdependent parts. 2.The system tends to move towards maintaining self order or balance.3.The system moves static, meaning that it will move on a regular change process.1.The nature of parts of a system will affect other parts.1.The Akam system maintains boundaries with its environment. 2.Allocation and integration are two important things needed to maintain system balance. 3. The system tends towards the collar of maintaining self-balance which includes maintaining boundaries and maintaining the relationship betweenthe divisionswith the whole system, controlling different environments and controlling the tendency to change the system from within.

Social system consists of a number of actors individual mutually interact in a situation that at least have an aspect of the environment or physical, actors are motivated in the sense of having a tendency for optimize satisfaction conjunction with their situation defined and mediated in terms of system a culturally structured shared symbol. Major issues in this social system include actors, interactions, environment, optimization, satisfaction, and culture Parson's, 1951. Things s fro important in the social system he discusses Parsons filed the functional requirements of the social system are: 1.The social system must be structured (orderly) so that it can operate in harmonious relationships with other systems. 2. To aintain the survival of the social system must get support from other systems. 3 . The social system must be able to meet the needs of its actors in a significant proportion. 
The social system must be able to give birth to adequate participation from its members. Social systems must be able to control potentially disruptive behavior .

\section{METHOD}

As a guide and approach in conducting and conducting research it is necessary to have a method. The research method is a work pattern of the implementation of research that must be taken to achieve the goal. The researcher is using research qualitatively. Qualitative research is a research procedure that uses descriptive data in the form of written words or answers from people whose behavior is observed Moleong, 2002.

This study is adjusted to the reality on the ground. Qualitative research does not aim to study or prove the truth of a theory but existing theories are developed using collected data. The approach in this study used a descriptive approach qualitative maksundnya to mendeskrifsikan author of what is, and is applicable in conducting the research in one place, in other words research descriptive aims to collect data in the form of written words of those people interviewed or observed at the time research.

The research was conducted in the District Pringgasela East Lombok high school / vocational school or equivalent, in particular SMAN 1 Pringgasela , by reason of this school operates a policy of zoning system PPDB school year 2018 /2019.

Research subjects are individuals, objects or organisms that are used as sources of information needed in the collection of research data. Another term used to refer to the subject of research is the respondent, that is, the person who responds to one treatment given to him. There are objections raised by Kerlinger about the term respondent, according to him the respondent is only appropriate for experimental research conducted not on humans. Among qualitative researchers, the term respondent or research subject is called an informant, that is, a person who provides information about the data the researcher wants in relation to the research being carried out. Perhaps this term is more appropriate to be used to refer to research subjects . Muhammad Idrus, 2007.

Moleong 2010. escribes the research subject as an informant, which means people in the research setting are used to provide information about the situation and conditions of the research setting. The research subjects used Purposive Sampling. Purposive Sampling serves to capture as much information as possible from various sources in order to explore what will be the basis of the emerging designs and theories. Porposive Sampling subjects in this study are; 1). Principal, 2). Students (students), who have the status of state- level high school / vocational school equivalent, on the grounds that they know about this research problem.
Data Analysis Techniques namely ; 1 . Data reduction (Data Reduction ) 2. resentation of data (Display Data) 3. Conclusion Drawing / Verivication ( 4 ) Conducting a final conclusion and describing it as a result of research. $\mathrm{K}$ eabsahan Data namely ; 1 . validity internal (Credibility) 2. Dependence Dependability / Reliability) 3. Certainty / objectivity (confirmability).

\section{RESULTS AND DISCUSSION}

\section{A. Positive Impact of PPDB Zoning Policy}

The zoning policy is one of the government programs that can produce equal distribution at the education unit level, especially in senior high schools / MAs. Therefore, this policy can cause various problems so that it can produce positive and negative impacts, especially schools, students, and student guardians.

1. Providing Equal Distribution Of Education

In this PPDB zoning policy it provides a balance for education units so that the equal distribution of students in schools in terms of admission of new students, so that in Talcott parson theory with the equilibrium there are no schools that are overburdened, this will make it easier for teachers who have received sergur (teacher certification ) because they have filled 24 hours with the number of school classes they teach. This was revealed. With the zoning policy can be beneficial for schools that are public and private as the main purpose of this zoning can produce equity in the process of admission of new students. The aim is to prevent students from concentrating in certain schools. It is said, the distribution of high school / vocational students in NTB is uneven. Students pile up in certain schools. Some schools apply double shift to accommodate as many students as possible. For example, in Pringgasela Subdistrict, several schools implemented morning and evening teaching and learning activities. This learning atmosphere is not fun.

\section{Provide Opportunities For Students Who Have} Potential

L ebih Further, the transition MA / SMK to the province will provide the public the better. During this time, many students from outside the school to Pringgasela . The impact of schools in other districts / cities is a shortage of students. Moreover, private schools, the accumulation of students in certain schools will reduce the quality of education so that the learning process is not optimal. One group is filled with more than 40 students. Learning like this will not be conducive. Moreover, until children learn during the day, this zoning system will later be applied to all schools in NTB. Students will go to school in the Subdistrict according to their place of residence. This is done to access equal distribution of students, there is no reason for parents to force their children in certain schools. All schools are the same. Students will go to 
school in their own area. This was revealed by one informant saying:

Students who are close to their domicile get the opportunity to enter favorite schools even though they have moderate and low potential. Students who have the potential will get the chance to become the overall champion because competition is lacking, especially in non-favorite schools. The policy is implemented, in addition to ensuring the distribution of students in all schools can be evenly distributed, ensuring access to equitable education for all poor and rich communities, as well as an effort to suppress cheating practices in each.

PPDB, besides the rampant practice of extortion (extortion), treatment and entrust leave during PPDB, because the distribution of students is only concentrated in urban schools, especially Favorite schools.

3. Can Facilitate The Control Of Parents To Students

If now with the zoning system, the term favorite school does not exist, prospective students cannot arbitrarily go to school and may only attend school according to the zoning where they live. Unless those who excel, prospective students may enter schools outside of their territory, but must go through a series of tests, competing with other high-achieving candidates, thus there is no discrimination.

The zoning policy in PPDB is also to ensure that all schools, especially rural schools, both public and private, can get students and not just pile up in schools in their favorite cities or schools. In addition, the acceptance of new students is poor now with the zoning system, must also be accepted and made free.

4. Opportunities For Students Who Are Less Capable In Academic Matters.

In this case students are given the opportunity to be able to carry out the learning process in vaforit schools even though they have less potential, so the opportunity to change their intellectuals is great by ways or methods of learning that have been carried out by a teacher in $\mathrm{a} \mathrm{v}$ - students enjoy the facilities / infrastructure that supports so that the child will experience $p$ Changes $i$ ntelektual.

5. Easily Students Come To School.

This zoning will have a positive impact on children who live near school, because in this day children do not need a long time to come to school, so the level of student delay is reduced. With this policy there is no reason for students to be late for school, because their residence is close and will require little time, because the delay in school children is caused by the distance of their residence. This has also been implemented by the government that children should not use transportation facilities to go to school because this policy makes it easy to travel three miles from school, except students who already have a Driving License (SIM) they will be given to use a vehicle to go to school .

\section{B. The Negative Impact of the PPDB Zoning Policy}

In this case the zoning policy for new student admissions has a negative impact on students, and parents, where schools that will produce student quality are slightly disturbed because people who have high intellectuals are not given a school outside their domicile.

\section{Lack of Student Learning Interest}

Children's learning motivation is caused by various factors such as school environment, friends, school facilities, how to teach teachers and others. In this case the lack of student interest in learning due to mismatch between expectations and reality, this gives students a reduced learning interest, which with reduced interest in learning will cause quality or potential to decrease. Schools are not looking for quality, but there is an even distribution between favorite and non-favorite schools, indicating that the competence of each school is declining, because in this school not only children who live to be smart and can carry the good name of the school, not a few children outside not domicile carry the good name of the school, both academic and nonacademic. Student learning interest is caused by various aspects in this case students feel less satisfied with their learning services so that there is no seriousness in following the learning process both academic and nonacademic. Academic, for example, they are not serious in teaching and learning (PBM), while the nonacademic aspects are reduced extracurricularly, for example, the implementation of adolescent scientific work (KIR), Olympics, sports, etc. This is what makes students feel uncompetitive. Feeling worried if children who have high competence do not get the opportunity to explore knowledge in schools that are well known for high quality / vaforit, this is what makes students' parents disappointed with the PPDB zoning system policy.

This policy also resulted in many schools which initially had a lot of classes being reduced so that in managing the education unit in terms of school operational costs decreased due to decreased student capacity.

\section{Lack of BOS School Income}

With this policy schools have decreased the number of students so that school operational costs have decreased because the number of students who initially increased to be reduced due to the impact of this policy. Funds that have been managed by the education unit will help in the learning process such as only completing school infrastructure so that the quality of the school experiences an increase, because in this boss the school is delegated to manage the funds. 
3. Prestai Children Become Less (Non-Favorid School)

The zoning policy in PPDB has both direct and indirect impacts that occur in the short and long term. First, open access of the poor to quality education. This is a positive impact that can be felt immediately . The zoning policy opens access to quality education for families with mediocre socio-economic abilities that are generally correlated with mediocre levels of academic achievement as well. Second, schools become more heterogeneous when viewed from the profile of students, both in terms of family background, economic level, and academic ability.

Heterogeneity can open school community insights (teachers, employees, students) about diversity which is the foundation of the diversity of the Indonesian nation. Third, in terms of the right to quality education, the zoning system limits the interests, talents, and preferences of individual students to choose the school they want. This issue has indeed been overcome by a policy of a quota of percent for high achieving children to be able to go to the school they want without going through zoning provisions. However, this quota still limits the aspirations of every student and parent to provide quality education rights for their children. The zoning policy in PPDB not only has an impact, both positive and negative, but also leaves problems that must be resolved quickly in the future. Problems that arise can occur due to demographic, psychological, and cultural factors . First, in terms of demographics, zoning policies instead of eliminating the paradigm of elite schools and not, in the long run they will widen the gap in quality disparities. Favorite and elite schools are generally located in the city center. High land prices in the city will only be affordable for rich families who are generally already very aware of the importance of education. Rich families will still get quality education services, while poor families, who are generally located in the periphery, will also get access to education with the quality of the periphery based on the zoning system. Second, from the psychological side, discomfort will occur.

Teachers feel uncomfortable because of the stability and stability that they have felt disturbed. Schools with good quality have high expectations of students so teachers who are accustomed to only managing smart and highly motivated children will experience frustration when meeting students with academic qualities that are far from their expectations. If this continues, in the future the school which is already good will actually drop in quality. Third, students from the poor will experience a cultural clash in the new school. Students will be surprised by the teachers' high expectations and study habits in the new school. If not resolved, this problem will become an obstacle to integration for students from economic backgrounds and low academic ability.

\section{CONCLUSION}

Based on the results of the study it can be concluded that the student's guardian's perception of the zoning policy in the acceptance of new students (PPDB). able to create an equal distribution in every school, both public and private status. Initially the number of students becoming much reduced in accordance with the rules of $\mathrm{P}$ he Government to inflate students do not occur, as well as schools that shifnya reduced to increase. Children who have the potential to tow idecreased quality of knowledge because they were educated in schools that was not his choice.

While the zoning policy can have positive and negative impacts, where the positive impact of the PPDB zoning policy is; Provide equal distribution of education, Provide opportunities for students who have potential, Can facilitate the control of parents to students,Opportunities for students who are less capable in academic matters . Easily students come to school . While the negative impact is namely; Lack of Interest in Learning Students, lack of revenue cost of Operations School (BOS), child's crowning achievement becomes less (non favorid school) Feeling concerned that children who have a high competence did not get a chance to multiply science in school quality is high. this is what makes students guardians disappointed with the PPDB zoning system policy. Schools are not looking for quality, but there is an even distribution between favorite and non-favorite schools, indicating that the competence of each school is declining, because in these schools not only children who live as intelligent children can bring the good name of the school, not a few children outside carry a good name both academic and non-academic schools.

\section{ACKNOWLEDGMENTS}

To the research members who have helped in completing this article both morally and materially, To the senior lecturers who have provided criticisms and suggestions which are very constructive so that the article is finished in accordance with what is expected, To the head of LP3M who has supported morally so that this writing can be finished.

\section{REFERENCES}

Alimandan. (1992). Sociology. Multiple Paradigm Science. Jakarta: Rajawali Press.

Arikunto. (1998). Research Procedure (A Practice Approach). Jakarta: Reneka Copyright.

Edi Subkhan, Darmaningtyas. (2012). Educational Policy Manipulation. Resist Book. Jakarta. 
Husman Kolip, Elly M Stiadi. (2010). Introduction to Sociology. Bandung: Kencana PrenadaMedia Group.

Ministry of Education, Culture. (2017). Permendikbud No 17 Concerning Admission Of New Students $(P P D B)$. Jakarta.

Martono, Nanang. (2011). Sociology Of Social Change. Jakarta: Rajawali press.

Martono, Nanang. (2012). Sociology Of Social Change: Classical, Modern, Postmodern, And Postcolonial Perspectives. Jakarta: Rajawali Press.

Moleong J Lexi. (2004). Qualitative Research Methodology. Bandung: Youth Rosdakarya.

Raho Bernard . (2007). Modern Sociology Theory. Jakarta: Literature achievement.

Ritzer George, Goodman J. Douglas. (2008). Sociological Theory From Classical Theory to the Latest Development of Postmodern Social Theory. Yogyakarta: Discourse Creation

Ritzer, George. (2011). Sociology of Multiple Leveled Sciences. Jakarta: Rajawali Press

Supardan, Dadang. (2011). Introduction To Social Science. Jakarta : Bumi Aksara.

Sugiono. (2009). Qualitative and R\&D Quantitative Research Methods. Bandung: Alfabeta.

Yoyon Bahtiar, Irianto. (2012). Kebijakan Pembaharuan Pendidikan Konsep Teori Dan Model. Jakarta: Rajawali Press. 